\title{
Corporate Social Responsibility in Hotel Businesses
}

\author{
Otel İșletmelerinde Kurumsal Sosyal Sorumluluk
}

\author{
Asst. Prof. Dr. Hakan Yılmaz - Asst. Prof. Dr. Sinan Yılmaz
}

\begin{abstract}
The present study examines CSR in hotels. The study begins with a review of the concept of CSR in light of corporate sustainability, corporate reputation and corporate communications. It employs case study methodology to examine the CSR implementation and initiatives of the Accor Group which is one of the leading hotel operators in the world. The Accor Group is present in 92 countries across five continents, owns, leases or manages 3700 hotel properties. It has a portfolio of 18 brands ranging from economy to luxury. The reason Accor Group is selected for the case study is its CSR program titled "PLANET 21" which covers 21 CSR initiatives covering 7 domains which it calls; health, nature, carbon, innovation, local, employment and dialogue. These domains cover a wide spectrum of CSR topics and represent a variety of stakeholder groups. Also the global nature of the company under examination ensures that different types of geographically classified CSR philosophies are covered. The findings of the case study are used to develop suggestions for hotel businesses desiring to develop CSR policies.
\end{abstract}

Keywords: Hotel Businesses, Corporate Social Responsibility, Corporate Communications

\section{Öz}

$B u$ araştırma otel işletmelerinde kurumsal sosyal sorumluluk (KSS) kavramını incelmektedir. Çalışma kurumsal sürdürülebilirlik, kurumsal itibar ve kurumsal iletişim ışığında KSS kavramının incelenmesi ile başlamaktadır. Örnek olay yöntemiyle, önde gelen küresel otel işletmelerinden biri olan Accor Group'un KSS girişim ve uygulamaları incelenmektedir. Accor Group, 92 ülkede, ekonomikten lükse uzanan 18 farkl marka altında, 3700 otel işleten bir otel işletmecisidir. Araştırmada Accor Group'un seçilmesinin nedeni; sağlık, doğa, karbon, yenilik, yerel, istihdam ve diyalog olarak adlandirdiğı yedi boyutta 21 KSS girişiminden oluşan "Planet 21" adlı KSS programı uyguluyor olmasidır. Bu programda ele alinan boyutlar, KSS başliklarına ilişkin geniş bir yelpazenin yanı sıra pek çok paydaş grubunu kapsamaktadir. İncelenen işletmenin küresel oluşu, coğrafi temelli olarak da sinfflandirılabilen farklı KSS felsefelerinin kapsanmasını sağlamaktadır. Bulgular ışığında KSS politikaları ve girişimleri geliştirme yönünde diğer otel işletmelerine yönelik öneriler geliştirmiştir.

Anahtar Kelimler: Otel İşletmeleri, Kurumsal Sosyal Sorumluluk, Kurumsal İletişim

\section{Introduction}

The information revolution and globalization have dramatically changed the business landscape. The evolution of the internet into a real-time medium of information exchange, removal of impediments to international business activities and in general increased global awareness of societies, have not only provided new opportunities for businesses but have also increased public scrutiny into business activities and consequences. Increased stakeholder sensitivity to environmental and social issues have begun to exert

Asst. Prof. Dr. Hakan Yllmaz, Anadolu University Faculty of Tourism, hyilmaz5@anadolu.edu.tr

Asst. Prof. Dr. Sinan Yllmaz, Bülent Ecevit University Faculty of Economics and Administrative Sciences, syilmaz@beun.edu.tr 
strong pressures on businesses that were envisioned neither by regulatory authorities nor business people. Hence, businesses' success, legitimacy and survival have become dependent on compliance not only with laws and rules set out by governments but on compliance with values, norms and expectations of stakeholders.

In the contemporary business world, profitability alone, even under full compliance with regulations, is not enough for ensuring sustainability. The various constituents and audiences of any business organization, also known as, stakeholders, expect businesses to fulfill their various responsibilities to the wider social and natural environment within which they exist. Corporate social responsibility (CSR) can be defined as doing business with a sense of responsibility towards the community and the environment. This sense of responsibility is reflected in doing business in ways to ensure minimal negative impacts on stakeholders while undertaking initiatives in various domains aimed at contributing to the community and the environment. CSR initiatives can cover a wide spectrum of domains including but not limited to culture, the arts, sciences, education, health, and environment. In essence CSR can be summarized as "doing good while doing well" or "doing well by doing good".

CSR implementation in businesses has two principle dimensions covering business operations and corporate communications. Successful CSR requires success in three critical operational domains; minimizing negative impacts, providing positive contributions to the society and environment beyond those dictated through legislation and regulations and earning adequate returns on resources employed to ensure a business's ability to meet the expectations of all stakeholders, internal and external. In this sense CSR becomes pivotal in both ensuring corporate sustainability and corporate reputation.

CSR is also closely related to corporate communications since its success requires active stakeholder engagement. Stakeholder engagement is defined as employing corporate communications in establishing a two way dialogue with constituents. This gives the business the opportunity to uncover the social and environmental concerns of stakeholders while giving stakeholders chance to influence business decisions.
Corporate communications can also be employed in CSR, although to a lesser overall effect, to influence stakeholders to agree with business decisions already made. In this regard corporate communications becomes one of the key tools for CSR and the ability to achieve triple bottom line and corporate sustainability.

Increased relevance and importance of CSR across the full spectrum of businesses has resulted in it becoming one of the prominent managerial topics. Tourism, which is becoming a major driver not only of economic development but cultural exchange and global awareness, has also adopted CSR. Increasing material wealth and living standards in developing nations mean that societies which until recently were relatively isolated from other parts of the world are becoming integrated. Worldwide development in transportation infrastructure is increasingly making any place on earth a potential destination for tourism. While considered, relatively, a low environmental impact industry, tourism too has potential negative impacts on its environment.

As one of the principle components of the tourism industry hotels, like all other businesses, seek profitability for economic sustainability and competitive advantage. Also, like all other businesses, hotels are not exempt from the forces that dictate compliance to stakeholder standards. Hence, CSR is very relevant for hotel businesses. Business decisions, operations and communications of hotels reflecting CSR awareness is no longer discretionary decisions but an implied mandate. Therefore CSR implementation through corporate communications by hotel businesses is fast becoming the standard for hotels.

The present study examines CSR in hotels. The study begins with a review of the concept of CSR in light of corporate sustainability, corporate reputation and corporate communications. It employs case study methodology to examine the CSR implementation and initiatives of the Accor Group which is one of the leading hotel operators in the world. The Accor Group is present in 92 countries across five continents, owns, leases or manages 3700 hotel properties. It has a portfolio of 18 brands ranging from economy to luxury. The reason Accor Group is selected for the case study is its CSR program titled "PLANET 21" which covers 21 CSR initiatives covering 7 domains which it calls; health, nature, carbon, innovation, lo- 
cal, employment and dialogue. These domains cover a wide spectrum of CSR topics and represent a variety of stakeholder groups. Also the global nature of the company under examination ensures that different types of geographically classified CSR philosophies are covered. The findings of the case study are used to develop suggestions for hotel businesses desiring to develop CSR policies.

\section{Definition of Corporate Social Responsibility}

Although CSR applications and implementation seem to have become popular relatively recently, it has a long and rich history. The notion that those with more means should have a sense of responsibility towards the less fortunate is a major underpinning of all moral and ethical systems, especially organized religion. The history of mankind has witnessed the evolution of concepts that are closely related to social responsibility, like charity and philanthropy. Especially in Islam, the concept of zakat, which is a compulsory form of charity (somehow equitable to income tax, but paid directly to those in need) all have in common the desire to contribute to social justice by ensuring the flow of scarce resources from the more endowed to the less endowed. However, the first instance of the use of social responsibility concept in a modern business framework is in the book titled "The Social Responsibilities of the Businessman" by Howard. R. Bowen in 1953 (Carroll, 1999).

By the late 19th century businesses were voicing concerns over the welfare of workers and the general impact of business activities on the society. The emergence of the labor rights movement and the social problems caused by the industrial revolution drove some businesses to undertake initiatives, albeit of limited scale, towards social welfare. These included building of hospitals, public baths and income subsidies like food coupons. The same period saw the rise of individual business philanthropists, like Rockefeller and Vanderbilt rise to fame in the US. This early period of social responsibility, if it can be called that, was characterized by the centrality of philanthropy. In most instances this was the result of the world view of the business owner. This resulted in a predominantly paternalistic form of philanthropy, where the businessman in question provided for the society's benefit what he deemed appropriate. This culminated in its most pervasive form in the concept of company towns which were in many instances mini utopias as envisioned by the philanthropist businessman in question (Carroll \& Shabana, 2010).

The shift towards CSR in the contemporary sense can be observed in the US in the post WWII period. In 1949 two articles, published two month apart in the Harvard Business Review can be seen as the precursors of the modern evolution of corporate social responsibility. The first of these was "Business Responsibilities in an Uncertain World" by Donald K. David, where he called on businessmen to become engaged in public issues beyond the immediate economic functions of their business. This was followed by "The Roots of Business Responsibility" by Bernard Dempsey, where he provided a philosophical foundation for responsible business practices. Dempsey suggested that the responsibilities of businessmen arose from four specific domains of justice; exchange, distributive, general and social. Exchange justice refers to trust underlying market transactions, distributive justice refers to the just relationship between the government and individuals, general justice refers to acceptance of legal frameworks and ethical obligations, finally, social justice refers to the obligation to contribute to the welfare and progress of the society.

The importance of CSR seems to have increased during the latter parts of the 20th century, especially in the USA. In Europe CSR found a place in the European Commission agenda in the 1990's. In 1993 Jaques Delors called on businesses to combat social exclusion and unemployment, resulting in the creation of European Business Network for Social Cohesion in 1996, which eventually evolved into CSR Europe, a platform of over 10000 enterprises (CSR Europe, 2015). The European Union sees CSR as an important tool in achieving sustainable development (Öztürk, 2013).

There are many definitions of CSR. Many concepts regarding corporations taking active part in providing social good are closely related to and are considered in conjunction with CSR (Dahlsrud, 2008). These include; corporate philanthropy, corporate charity, corporate giving, social activities of corporations, social relations, social communications, social development, local-global identity management, social marketing of corporations. Here, social good 
does not refer to what is legally required or socially expected commercial activities. Volunteerism is central in providing social good within the concept of CSR (Göztaş, 2013).

As previously stated the first instance of the use of social responsibility concept was in Bowen's book titled "The Social Responsibilities of the Businessman". Bowen defines social responsibility as the obligation of businessmen to pursue policies, take decisions and to act in ways that are desirable in terms of the objectives and values of the society (Hamarneh, 2013). The notion that businesses should be socially responsible expanded and spread throughout the 1960's with the increasing prominence of multinational corporations (Lantos, 2011). The concept of social responsibility evolved into corporate social responsibility during the 1980's and by the 1990's deciding and acting in support of a social issue became necessary for a company to be positively perceived and receive positive press (Holcomb et al., 2007). By the new millennium "doing good while doing well" became the driving motto for most businesses. Primacy is paced on programs that overlap with corporate values and support organizational goals and on issues targeted towards principal products and main markets (Göztaş, 2013).

In their study titled "Making Good Business Sense", published by the World Business Council for Sustainable Develeopment (WBCSD) Holme and Watts (2000) offer this definition: "CSR is the continuing commitment by business to behave ethically and contribute to economic development while improving the quality of life of the workforce and their families as well as the locale community and society at large". CSR is related to how the business is operated. It entails meeting or exceeding legal, commercial, public and ethical expectations that a society has of business. It is more than a collection of individual initiatives or occasional gestures motivated by business benefits like public relations or marketing. It is a comprehensive set of practices, policies and programs integrated in business operations and decision making processes with the support and encouragement of top management.

In October 2011 the European Commission initiated a new agenda regarding CSR. The EC had previously defined CSR as "A concept whereby companies decide to voluntarily contribute to a better society and cleaner environment. A concept whereby companies integrate social and environmental concerns in their business operations and in their interaction with stakeholders on a voluntary basis". In the new agenda the EC redefined CSR as "the responsibility of enterprises for their impacts on society" (Öztürk, 2013). According to the new EC agenda, in order to meet their corporate social responsibilities enterprise should have in place a process to integrate social, environmental, ethical, human rights and consumer concerns into their business operations and core strategy in close collaboration with their stakeholders. The main focus here was put forth as maximizing the creation of shared value for the shareholders, other stakeholders and the society and identifying, preventing and mitigating possible adverse impacts of business operations.

CSR should be developed by businesses themselves. Governments can support CSR through policies that encourage volunteerism, transparency and responsibility, or, when necessary, through legislation regarding taxation and subsidization. Businesses should be flexible in their CSR approaches and attempt to be innovative. Flexibility and innovation will enable them to undertake CSR initiatives that are more meaningful for stakeholders (Pelit et al., 2009). Presently, CSR is relevant for all businesses in all industries. It is one of the principle drivers of legitimacy and acceptance by society. It contributes to both the relative social standing and the bottom line of a business.

\section{Corporate Social Responsibility in Tourism}

The importance and prominence of CSR in tourism, which is a rapidly growing industry that contributes to local and regional economic development and an important driver of globalization is increasing. Although many businesses have not yet grasped in full the importance of sustainability CSR has become one of the important concepts for businesses (Hamarneh, 2013). In effective management CSR provides benefits through recognition and workers commitment. CSR is also beneficial in establishing good relationships with strong partners. Increasing effects of tourism on the society increases ethical and social issues regarding not only business associations and stakeholders but also local communities and the environment. Effective and positive management of these relationships between industry and society is performed through CSR. 
Tourism has important environmental, social and economic impacts. Therefore the engagement in CSR, especially in sustainable and environmentally responsible tourism applications is not surprising. This requires all businesses to be aware of their responsibilities and decide on the actions to be taken. This necessitates new and innovative approaches to CSR, including but not limited to; ecolabeling, awarding, ethical, social and environmental management systems, environmental performance system, employment practices, social responsibility reporting and transparency. The number of businesses undertaking such initiatives or developing these management systems increase every day, making these concepts part of their routine operations.

Until the 1980's the main focus was on certification programs and priority was on voluntary initiatives. Since then social and community issues have also found place in the social responsibility focus of corporations. This is attributable to Agenda 21, a voluntary action plan regarding sustainable development initiated by the UN. Agenda 21 which was initiated in 1992, found a response in the tourism industry in 1996 when three international organizations, the World Travel and Tourism Council (WTTC), the World Tourism Organization and the Earth Council joined together to launch an action plan titled "Agenda 21 for the Travel and Tourism Industry: Towards Sustainable Development", which is a sectoral sustainable development program based on the original UN initiative (Halcomb et al., 2007).

The tourism sector have developed a number of sectoral CSR initiatives (Smith \& Ong, 2015). International Hotels Environment Initiative (IHEI) is an example. IHEI which has over 11000 members offers services on environmental management. The organizations publications help hotels throughout the world in increasing standards of their environmental initiative and help them in controlling costs in these initiatives (Hamarneh, 2013). There are also two important organizations in Europe; European Federation of Food, Agriculture and Tourism Trade Unions (EFFAT) and European Trade Association of Hotels, Restaurants and Cafes (Hotrec). These organization organize initiatives and activities for their members' benefits on topics including; equality of opportunity, working conditions, discrimination, fair pay, lifelong learning, health and safety, employee relationships, among others (Holcomb et al., 2007).

Hotels which are one of the principle components of tourism industry, like all other businesses, strive for profitability in order to ensure their survival. In today's world, though, it is becoming increasingly difficult for businesses which are solely focused on profitability, without regard discharging social responsibilities to be sustainable. This changed business environment is valid for hotel businesses too. The financial returns alone do not ensure survival, without employing their financial resources in activities to benefit the society at large they find their chances of long term survival diminishing. Therefore, designing management and communications strategies with an emphasis on corporate social responsibility is becoming a basic requirement for hotel businesses. Performing corporate social responsibility initiatives are not enough by itself, they also need to communicate these efforts to their stakeholders to increase awareness and support.

In this regard hotel businesses are also able to employ CSR initiatives as a marketing communication tool.

Organizations like "Green Hotels" on the other hand are environmental initiatives and are common. Green Hotels are an association of green hotels and focus on issues like waste reduction, water and energy conservation (Holcomb et al., 2007). Blue flag program can also be considered within the scope of CSR, since it is a non-profit, sustainable development initiative in the form of an eco-labeling system focused on restrictive criteria regarding marinas and beaches.

CSR initiatives should be measurable by the stakeholders on all activities and operation of a business and should be focused on not just economic but also social and environmental sustainability. Even though sustainability had initially been considered mostly regarding environmental issues, presently it is closely related to social and community issues too. The contemporary sustainable tourism understanding takes into consideration the quality of life of both the visitors and the hosts, beyond just environmental preservation. Sustainable tourism is closely related to harmonization between tourism and the resources and needs of the destination. 
For hospitality business creating customer satisfaction and acting in accordance with CSR principles is not only about product and service production but also the presentation, promotion and marketing of these products and services. This requires acting in accordance to CSR principles by being honest in advertisement and promotion and being careful not to misuse stakeholder trust (Türker and Uçar, 2013).

In tourism CSR has gained much prominence in the last decade. Still, the emphasis being placed on CSR in the tourism and hospitality industry is not enough. The share of tourism and hospitality in total number of CSR initiatives is relatively low. This is due to a number of factors like; the fact that most of the businesses in the industry tend to be small or medium sized enterprises, that the industry is delicately balanced and the volatility in demand.

In the tourism and travel industry most CSR initiatives are undertaken by the larger actors. A few examples of CSR implementation in the tourism industry include the Inter Continental Group, the Marriott chain and the Thomas Cook Group.

Inter Continental Group PLC (IHG) has 3300 businesses spread throughout 100 countries. It employs a CSR centered management system and has integrated CSR well into its culture. It has successful initiatives like energy and water conservation to minimize negative impact. It has active corporate giving projects and beyond mere philanthropy. It acts responsibly towards cultural, natural and environmental heritage. It also supports local communities through local procurement, support for local education and employing locally. It has a close relationship with National Geographic.

The Marriott is one of the largest hotel chains with 3100 units in the US and 66 units in other countries. It is the first hotel to cooperate with Conservation International. Marriott has five key CSR initiatives focusing on water and energy conservation, waste reduction, supply chain management, green buildings, protecting the rainforests, customer and employee relationships (Halcomb et al., 2007).

Thomas Cook Group PLC is the second largest tour operator in Europe and have begun recently to publish annual sustainability reports. These reports cover the CSR activities undertaken by the group. These initiatives include group work, improvements on environmental management, awards and economic aid to Haiti earthquake victims.

Accor Group is recognized by Holcomb et.al. (2007) as the best CSR reporting hotel company. Although the group does not publish a dedicated sustainability report per say, it includes a large section dedicated to sustainability reporting in its annual report. The group also has a dedicated section in their website on sustainability, which is what they label CSR as. They have a number of initiatives about which they provide information.

\section{Corporate Social Responsibility in Hotel Business: Case of Accor Group}

The Accor group is one of the largest international hotel chain in the world. They operate in 92 countries. They own, lease, manage or franchise 3700 hotels with 480000 rooms. They employ over 170000 workers and have 14 brands. It was founded in 1967 when the first Novotel was opened in Lille Lesquin, near the Belgian border in France. It established the Ibis brand in 1974, acquired the 3 star chain Mercure in 1975 and in 1980 acquired the 4 star chain Sofitel. In 1983 the Accor group was formally created, at the time it had presence in 45 countries, with 35000 employees across 440 hotels and 1500 restaurants. Its current portfolio of brands covers the full spectrum of hotel business; economy, midscale, upscale and luxury. These brands include; Sofitel, Pullman, MGallery, Grand Mercure, the Sebel, Novotel, Mercure, Adagio, Ibis, Hotel F1 and Formule 1 (Accor, 2013).

According to their consolidated financial statements for 2014; they have a revenue of 5.454 billion $€$, a net profit of 240 million $€$ and a total profit of 309 million $€$. Their assets are valued at 8.755 billion $€$, of which 984 million $€$ are goodwill and other intangible assets. Shareholder equity in the business is valued at 3.867 billion $€$. (Accor, 2014). They are listed in the Euronext Paris exchange (stock code: AC) and the London Stock Exchange (stock code: OH59). The share is trading at approx. $48 €$ first week of May, 2015. It is overall a profitable company 
Accor groups first initiatives towards sustainability dates back to 1994 when they established the Group Environmental Department. Before that, in 1985 they had established Académie Accor for human resource development. In 1997 they introduced an environment charter to help hotels in deploying sustainable development initiatives. In 2008 the Accor Foundation was established to organize outreach initiatives. 2009 saw the launch of Accor Plant for the Planet program, which is a part of UN organized reforestation project. In 2011 the group introduced an international diversity charter. 2012 saw the establishment and launch of Planet 21, a comprehensive CSR program. In 2013 the foundation was transformed into Solidarity Accor, which became the group's community endowment fund. Developing various sustainability programs over time the Accor group is listed in the FTSE4Good, Euronext Vigeo Europe 120, Ethibel Sustainability Indexes, and the UN Global Compact 100 indexes. These indexes mostly rate companies on other than financial criteria to help investor make investment decisions based on non-financial criteria, like social responsibility, ethical compliance, environmental impact etc (Accor, 2015a).

Accor group's CSR program is called Planet 21. It is presented as a comprehensive sustainability program in a similarly named section of their website. The company publishes their sustainability report (CSR report) as a part of their annual report. The program was launched in 2012 with goals set for 2015 . The programs name is a reference to Agenda 21, a UN program announced in Rio in 1992 (Go Green, 2013). The program is run by an executive vice-president for sustainable development. Establishing such an executive position in the upper level managerial board of the company can by itself seen as a sign of how serious the company is in their commitment to the program. The program is also referenced in their strategic vision communication (Accor, 2015b).

According to Sophie Flak, the current executive vice president, sustainable development, Accor places sustainability at the heart of their strategy. She gives as evidence the fact that in 2012 before the deployment of the program only $24 \%$ of their hotels had met the high standards set in the program and by the end of the first year of deployment $61 \%$ of hotels made notable improvements and $31 \%$ had been certified sustainable and verified by a third party (Ryan, 2013).

The Planet 21 program is built around seven important themes that the company calls pillars. These are; health, nature, carbon, innovation, local, employment and dialogue (Accor, 2012). For each theme three goals are set forth. These can be seen in Table 1.

Table 1. Seven Pillars and Associated Goals of Planet 21

\begin{tabular}{|c|c|}
\hline Pillar & Goal \\
\hline \multirow{3}{*}{ Health } & 1. Ensure healthy interiors \\
\hline & 2. Promote responsible eating \\
\hline & 3. Prevent disease \\
\hline \multirow{3}{*}{ Nature } & 4. Reduce water use \\
\hline & 5. Expand waste recycling \\
\hline & 6. Protect biodiversity \\
\hline \multirow{3}{*}{ Carbon } & 7. $\quad$ Reduce energy use \\
\hline & 8. $\quad$ Reduce $\mathrm{CO} 2$ emissions \\
\hline & 9. Increase the use of renewable energy \\
\hline \multirow[t]{3}{*}{ Innovation } & 10. Encourage eco-design \\
\hline & 11. Promote sustainable building \\
\hline & 12. Introduce sustainable offers and technologies \\
\hline \multirow{3}{*}{ Local } & 13. Protect children from abuse \\
\hline & 14. Support responsible purchasing practices \\
\hline & 15. Protect ecosystems \\
\hline \multirow{3}{*}{ Employment } & 16. Support employee growth and skills \\
\hline & 17. Make diversity an asset \\
\hline & 18. Improve quality of work life \\
\hline \multirow{3}{*}{ Dialogue } & 19. Conduct business openly and transparently \\
\hline & 20. Engaged franchised and managed hotels \\
\hline & 21. Share commitment with suppliers \\
\hline
\end{tabular}


There are two principle studies conducted by the Accor group in 2011 that serve as the basis for the Planet 21 programs. The studies are called the Earth Guest Research and include a guest tracking study and an environmental footprint study. Guest tracking study was published in June 2011, with the name "Sustainable Hospitality" (Accor, 2011a) while "Environmental Footprint" (Accor, 2011b) study was published in December 2011.

Sustainable Hospitality study was conducted in 6 countries where 6973 guests were surveyed. The study found that $76 \%$ of hotel guests were aware of the concept of sustainable development. $81 \%$ were able to spontaneously able to name a hotel related sustainable development theme. $67 \%$ of the guests indicated that ordinary citizens had a role to play in sustainable development while $63 \%$ indicated that corporations had a role. $51 \%$ of the guests indicated that they took into account sustainable development as a major factor in choosing a hotel. $68 \%$ indicated that they would choose a hotel at a more inconvenient location in favor of sustainable development. $66 \%$ were willing to shoulder added costs related to sustainability. $66 \%$ responded that sustainable hotels are not necessarily less comfortable. Lastly, 75 percent of respondents indicated that in hotels they acted equally or more concerned with sustainability (Accor, 2011a).

The Environmental Footprint study, on the other hand, is largely an internal audit. This study employed a life cycle analysis approach to measure the impact of Accor's core business operations on the environment. The analysis tracks the life cycle of value creation inputs to arrive at outputs. The analysis was applied to eleven key activities resulting in five important impacts (Accor, 2011b). These activities and impacts are presented in Table 2. Internal operations data was used to calculate the impact generated by the activities to establish baselines and improvement targets. In essence the Environmental Footprint study provided the backbone for the sustainability performance measurement and management system put in place in the Planet 21 program (Accor, 2015b).

Table 2. Selected Activities and Impacts at Accor

\begin{tabular}{|c|c|}
\hline Activities & Impact \\
\hline $\begin{array}{l}\text { - } \quad \text { Water consumption and release } \\
\text { - }\end{array}$ & $\begin{array}{ll}- & \text { Energy Consumption } \\
\text { - } & \text { Waste Production } \\
\text { - } & \text { Greenhouse gas }(\mathrm{CO} 2) \text { emissions } \\
\text { - Water pollution }\end{array}$ \\
\hline
\end{tabular}

Source: Accor (2013).

Analyzing internal data Accor was able to calculate the impact caused by each activity and the share each activity had on total impact. This provided the necessary inputs to identify and develop the sustainability initiatives to be undertaken. This data is presented in Table 3. It should be noted that the impacts presented here are the total impact for any activity in the whole of the value chain. For example, it can be noted that food and beverage accounts for $86 \%$ of the water consumption caused by Accor's activities, not $86 \%$ of Accor's water consumption. Food and beverage accounts for $94 \%$ of water pollution related to Accor, although, most of this pollution is not done by Accor per se, it is mostly caused during food and beverage production in farms and factories (Accor, 2015b). 
Table 3. Contribution of the Main Activities of Hotels to Impacts

\begin{tabular}{|l|c|c|c|c|}
\hline Impact & $\mathbf{1}^{\text {st }}$ Contributor & $\mathbf{2}^{\text {nd }}$ Contributor & $\mathbf{3}^{\text {ra }}$ Contributor & $\mathbf{4}^{\text {In }}$ Contributor \\
\hline $\begin{array}{l}\text { Energy } \\
\text { consumption }\end{array}$ & $\begin{array}{c}\text { Onsite energy use } \\
(75 \%)\end{array}$ & $\begin{array}{c}\text { Air conditioning } \\
(12 \%)\end{array}$ & $\begin{array}{c}\text { Laundry } \\
(7 \%)\end{array}$ & $\begin{array}{c}\text { Food and } \\
\text { beverage }(6 \%)\end{array}$ \\
\hline $\begin{array}{l}\text { Water } \\
\text { consumption }\end{array}$ & $\begin{array}{c}\text { Food and beverage } \\
(86 \%)\end{array}$ & On site water use & Air conditioning \\
$(11 \%)$ & Onsite energy use \\
Waste & Construction and & Onsite energy use & Operating wastes & Air conditioning \\
production & renovation $(68 \%)$ & $(26 \%)$ & $(5 \%)$ & $(1.1 \%)$ \\
\hline $\begin{array}{l}\text { Greenhouse } \\
\text { emissions }\end{array}$ & Onsite energy use & Food and & Air conditioning & Employee travel \\
$(66 \%)$ & beverage (14\%) & $(12 \%)$ & Air conditioning \\
\hline $\begin{array}{l}\text { Water } \\
\text { pollution }\end{array}$ & Food and beverage & On site water use & Laundry & $(0 \%)$ \\
\hline
\end{tabular}

Using the findings from these and other studies the Accor group developed the Planet 21 sustainability program. The program identifies active participation of both and guests as a key factor for success of the program. The program was initiated in 2012 using the data gathered from the previously mentioned studies to establish baselines and 2015 targets. As of the end of 2014, as reported in their annual report the program have met some of the targets while there is still room for improvement in some areas (Accor, 2015b).

The first pillar, or commitment area identified in Planet 21 program was health. The commitments related to this area ere; insuring healthy interiors, promoting responsible eating and prevention of diseases. The performance indicator for ensuring healthy interior was using eco-labeled products with the 2015 goal being $85 \%$ of hotels realizing this goal. At the end of 2014 this goal was exceeded with $97 \%$ of hotels using eco-labeled products, up from $95 \%$ in 2013 and $89 \%$ in 2012. Promotion of responsible eating was tied to the objective that $80 \%$ of hotels with restaurants should promote balanced dishes. The goal had been achieved at the end of 2014 with $97 \%$ of hotels with restaurants promoting balanced dishes, up from $96 \%$ in 2013 and $87 \%$ in 2012. Disease prevention was tied to the performance indicator whereby $95 \%$ of hotels would organize disease prevention training for employees. As of the end of 2014, 74\% of hotels had organized disease prevention training for employees, which was $69 \%$ in 2013 and $40 \%$ in 2012 .
The second pillar is nature, where the identified issues are reducing water usage, expanding waste recycling and protecting biodiversity. The 2015 goals are water use reduction $15 \%$ over 2011 , having $85 \%$ of hotels recycle their waste and having $60 \%$ of hotels participating in Plant for the Planet reforestation project. By 2014 water use reduction had reached 5.6\% over 2011, the 2013 attainment had been 5.4\% and 2012 reduction had been 5\%. By 2014 88\% of hotels were recycling their waste, up from $86 \%$ in 2013 and $79 \%$ in 2012. In $201446 \%$ of the hotels were participating in Plant for the Planet program. The participation rate in 2013 was $41 \%$ and in 2012 it was 39\%.

Third pillar of the program is carbon emissions where the Accor group aims to help in reduction of greenhouse effect causing emissions by reducing energy use, reducing their $\mathrm{CO} 2$ emissions and increasing the use of renewable energy. Accor group aims to achieve $10 \%$ reduction in energy use in their hotels over 2011 levels. By 2014 they had achieved a 4.5\% reduction, which was $0.3 \%$ in 2013 and a $3 \%$ increase in 2012 . So in 2013, even though energy use reduction was only $0.3 \%$ over 2011 , it was in reality $3.3 \%$ over 2012 . For CO2 emission reduction Accor aims to achieve 10\% reduction over 2011 levels by 2015. In 2014 they had achieved $3.8 \%$ reduction over 2011 . The reduction rate in 2013 had been $0.8 \%$, while in 2012 there had been a $10 \%$ increase over 2011. Accor aims to have $10 \%$ of their hotels using alternative sources of energy by 2015 . In 2014 they had achieved $9 \%$, an increase over 2013 (7\%) and 2012 (6\%) levels. 
The fourth pillar in the Planet 21 program is Innovation. Accor has listed under this category, encouraging eco-design, promoting sustainable buildings and introducing sustainable offers and technologies. The 2015 aim for eco-design is having at least $40 \%$ of their hotels have three or more eco-designed components. The level of achievement for 2014 was $40 \%$, an improvement over 2013 (35\%) and 2012 (23\%). The performance measure for promoting sustainable building is having 21 new or renovated hotels certified as sustainable buildings by 2015. In 2014 the level of attainment had been 13, which was 6 and 2 in 2013 and 2012, respectively. For introducing responsible hotel offers and technologies Accor group had selected having $20 \%$ of their hotels offer green meeting solutions by 2015 as the performance measure. However, the activity reports for 2014, 2013 or 2012 do not offer any data about realization levels for this measure.

The fifth pillar of the program is titled local. The initiatives listed under this heading are protecting children from abuse, developing responsible procurement practices and protecting the ecosystem. Performance measure for protecting children from abuse is given as having $70 \%$ of their hotels pledging to protect children where the actualization level for 2014 was $48 \%$, an increase from 2013 and 2012 levels of 44\% and 23\% respectively. The group aimed to have $70 \%$ of their hotels that have restaurants purchase and promote locally sourced products by 2015 . They exceeded this goal in 2014 with $87 \%$ of their hotels meeting the target, which was an increase over the 2013 level of $81 \%$ and 2012 level of $68 \%$. Accor groups target for protecting the ecosystems was have $100 \%$ of their restaurants ban endangered seafood from menus. They have achieved 93\% level in 2014, in improvement over the $89 \%$ level of 2014 and $83 \%$ level of 2012 .

The sixth pillar in the Planet 21 program by Accor group is titled employment. As with all other pillars there are three main goals associated with this heading. There are; supporting employee growth and skill, making diversity an asset and improving quality of work life. The performance goal for promoting growth and skill is identified as having $75 \%$ of hotel General managers promoted from within the organization by 2015 . The 2014 level of attainment is $69 \%$ which is a significant decrease from the 2013 and 2012 levels of $80 \%$. The group aims to have women make up 35\% of General Managers by 2015. They achieved a $27 \%$ level in 2014 which is drop from the
2013 level of 28\%. This measure in effect returned to 2012 level, which also was $27 \%$. Accor goal for improving quality of work life was stated as having all $(100 \%)$ of country organizations conduct employee opinion surveys every two years by 2015 . As they have operations in 92 countries the performance levels of 55 countries in 2014, 59 countries in 2013 and 71 countries in 2012 points to a clear downward trend in achieving this goal.

The final pillar of the program is titled dialogue. Conducting business openly and transparently, engaging franchised and managed hotels and sharing the Planet 21 approach with suppliers. Accor aims to have the company listed in 6 internationally recognized socially responsible investment indices by 2015 . The number of indices that the company is listed in 2014 was 3, a drop from 4 in 2013 and 2012. For engaging franchised and managed hotels Accor set having 40\% of all non-budget segment hotels ISO 14001 certified by 2015 their goal. They had achieved $41 \%$ certification rate in 2014, a vast improvement from 2013 level of $36 \%$ and 2012 level of $31 \%$. Accor group aims to share their approach with all (100\%) of their suppliers by 2015 through compliance with their Procurement Charter 21 program. In 2014 80\% of their suppliers were in compliance, which is a vast improvement over 2013 level of $68 \%$ and 2012 level of $60 \%$.

As of end of 2014 the Accor group have met 6 of their 21 Planet 21 goals for 2015. The have recorded improvements on 11 goals and are getting degraded results on 4 goals. The degradation is especially clear in their initiatives regarding employees, while they are achieving stellar results in their initiatives towards the environment.

\section{Conclusion}

In essence, corporate social responsibility is built around a philosophy that centers on sustaining a business while voluntarily contributing positively to the various environments within which the business takes place. Hence, it can be said to represent the "conscience" of a business. In a context where businesses are expected to be more respectful to nature, people and the future, hotel businesses are also driven to do their share. Increasing sensitivity exhibited by tourists as reflected by preference towards hotels towards that act more ethically and responsibly serve to increase 
the strategic value of social responsibility initiatives. Improving the working conditions of employees, environmental awareness and increasing efficiency and effectiveness of natural resource use are some of the prominent social responsibility initiatives that hotel businesses are focusing on.

CSR and sustainability is a very important factor for business survival. This holds true for hotel businesses just as it does any other business. Type. Accor group, which is one of the largest multinational hotel chains have undertaken a comprehensive CSR program titled Planet 21. In this program they have identified 7 key areas for CSR and have initiated 21 initiatives for implementation. The program which was initiated in 2012 is in its fourth year and the data for three years show that while environmental and operational initiatives result in success social initiatives tend to be more difficult to bring to fruition. The Accor experience can provide an example for other hotel businesses in their efforts to initiate CSR approaches.

This research focuses on a single multinational hotel chain that operates globally. Further research, focusing of social responsibility initiatives of different hotel businesses may yield different results. Also the social responsibility initiatives of hotels can be examined depending on their operation type. What hotel businesses need to keep in mind is that corporate social responsibility is a long term investment. As a result the relevant policies and initiatives too need to be long term oriented. Therefore, it will not be wise to expect immediate or short term returns from investment in corporate social responsibility.

Every hotel can develop a social responsibility understanding that better reflects its own characteristics and structure. Social responsibility strategies can vary depending on operation type, cultures of the countries operated in, size, future investment decisions and partnership structure, among other dimensions. Instead of trying to implement a standard social responsibility a custom strategy reflecting the above variables will probably be more appropriate. What is of importance is that businesses should identify a welldefined set of social responsibilities. This is especially important since social responsibility is not an issue that concerns just the business. It is an issue that is of concern to all businesses. Hotel businesses, like all other businesses should perform their share.

\section{References}

ACCOR (2011a). Sustainable Hospitality. Access: http:// www.accorhotels-group.com/fileadmin/user_upload/Contenus_Accor/Developpement_Durable/ img/PLANET_21/docs/EN/20110624_accor_sustainablehospitality_readytocheckin_bd_en.pdf.

ACCOR (2011b). Environmental Footprint Study. Access: http://www.accorhotels-group.com/fileadmin/ user_upload/Contenus_Accor/Developpement_ Durable/pdf/earth_guest_research/2011_12_08_ accor_empreinte_environnementale_dp_bd_ en.pdf.

ACCOR (2012). The 7 pillars of PLANET 21. Access: http://www.accor.com/en/sustainable-development/the-7-pillars-of-planet-21.html.

ACCOR (2013). Business Review Accor 2013. Access: http://www.accorhotels-group.com/fileadmin/ user_upload/Contenus_Accor/Finance/PDF/2014/ UK/2013_business_review_accor.pdf.

ACCOR (2014). Business Review. Access: http://www. accor.com/fileadmin/user_upload/Contenus_Accor/Finance/PDF/2015/UK/plaquette_gb_accor_ groupe_2014.12.pdf.

ACCOR (2015a). AccorHotels' Strategic Vision. Access: http://www.accorhotels-group.com/en/group/accorhotels-strategic-vision.html.

ACCOR (2015b). Sustainable development. Access: http://www.accorhotels-group.com/en/sustainable-development.html.

Bowen, H. R. (1953). Social Responsibilities of the Businessman. New York: Harper and Row.

Carrol, A. B. \& Shabana, K. M. (2010). The Business Case for Corporate Social Responsibility: A Review of Concepts, Research and Practice International Journal of Management Reviews, 12 (1), 85-105.

Carrol, A. B. (1999). Corporate Social Responsibility Evolution of a Definitional Construct" Business \& Society, 38 (3), 268-295. 
CSR EUROPE ( 2015). CSR History: 20 years of business-policy interaction driving the CSR movement. Access http://www.csreurope.org/history.

Dahlsrud, A. (2008). How corporate social responsibility is defined: an analysis of 37 definitions Corporate Social Responsibility and Environmental Management, 15 (1), 1-13.

GO GREEN (2013). Accor launches new sustainable development program - PLANET 21. Retrieved June 5, 2015, from http://www.go-green.ae/greenstory_view.php?storyid=2028.

Göztaş, A. (2013). Halkla İlişkilerde Stratejik Uygulamalar. Özgür, A.Z. (Ed). Halkla İlişkiler Eskişehir: Anadolu Üniversitesi Yayınları, No: 2713.

Hamarneh, I. (2013). Corporate Social Responsibility as a competitive advantage in Tourism sector. Journal of Tourism \& Services, 4 (7), 36-51.

Holcomb, J. L.; Upchurch, R. S. \& Okumus, F. (2007). Corporate social responsibility: what are top hotel companies reporting? International Journal of Contemporary Hospitality Management, 19 (6), 461475.

Holme, L. \& Watts, R. (2000). Corporate Social Responsibility: Making Good Business Sense. Conches-Geneva: The World Business Council for Sustainable Development.
Lantos, G. P. (2001) The Boundaries of Strategic Corporate Social Responsibility. Journal of Consumer Marketing, 18 (7) 595-630.

Öztürk, C. (Ed) (2013). Kurumsal Sosyal Sorumluluk Kavramı ve Gelişimi. Öztürk, C. (Ed) Kurumsal Sosyal Sorumluluk. Eskişehir: Anadolu Üniversitesi Yayınları, No: 3021.

Pelit, E., Keleş, Y. \& Çakır, M. (2009). Otel İşletmelerinde Sosyal Sorumluluk Uygulamalarının Belirlenmesine Yönelik Bir Araştırma, Yönetim ve Ekonomi, 16 (2), 19-30.

Ryan, R. (2013). Accor waves the sustainability flag. Access http://www.hospitalitymagazine.com.au/ accommodation/accor-waves-the-sustainabilityflag.

Smith, R. A. \& Ong, J. L. T. (2015).Corporate Social Responsibility and the Operationalization Challenge for Global Tourism Organizations Asia Pacific Journal of Tourism Research, 20 (5), 487-499.

Türker, N. \& Uçar, M. (2013). Konaklama İşletmelerinin Sosyal Sorumlulukları. İsletme Araştırmaları Dergisi, 5 (3), 155-183. 